\title{
AKTIVITAS SEDIAAN GEL ANTISEPTIK TANGAN BERBAHAN AKTIF EKSTRAK FRAKSI ETANOL DAUN SUNGKAI (PERONEMA CANENCENS JACK.) TERHADAP BEBERAPA BAKTERI PATOGEN
}

\author{
Arsyik Ibrahim ${ }^{1}$, Indah Woro Utami ${ }^{1}$, Risna Agustina ${ }^{2}$ \\ ${ }^{1}$ Bagian Biologi-Mikrobiologi Farmasi \\ ${ }^{2}$ Bagian Farmasi Klinik \\ Fakultas Farmasi, Universitas Mulawarman, Samarinda, Kalimantan Timur
}

\begin{abstract}
ABSTRAK
Penelitian Aktivitas Sediaan Gel Antiseptik Tangan Berbahan Aktif Ekstrak Fraksi Etanol Daun Sungkai (Peronema Canencens Jack.) telah dilakukan. Penelitian ini bertujuan mengetahui aktivitas antiseptik fraksi daun Sungkai ( $P$. canescens. Jack) secara in vitro terhadap beberapa bakteri patogen dalam sediaan gel antiseptic tangan dan mengetahui konsentrasi terbaik fraksi etanol daun Sungkai ( $P$. canencens Jack.) dalam sediaan gel antiseptik tangan terhadap masing-masing strain mikroba patogen. Bahan uji diperoleh dengan fraksinasi ekstrak fraksi etanol daun sungkai, selanjutnya formulasikan ke dalam basis gel antiseptic, diuji aktivitasnya terhadap beberapa bakteri pathogen dan menentukan konsentrasi terbaik fraksi etanol daun Sungkai ( $P$. canencens Jack.) dalam sediaan gel antiseptik tangan terhadap bakteri Escherichia coli, Salmonella thyposa, Staphylococcus aureu, Bacillus subtilis. Metode pengujian antibakteri mengunakan uji difusi padat secara in vitro. Hasil penelitian menunjukan konsentrasi fraksi etanol dalam sediaan gel antiseptik aktif terhadap bakteri Escherichia coli, Salmonella thyposa, Staphylococcus aureus dan Bacillus subtillis. Konsentrasi terbaik ekstrak etanol dalam sediaan gel antiseptik adalah $4 \%$ efektif menghambat/membunuh ke tiga bakteri uji.
\end{abstract}

Kata kunci : P. canencens Jack, Gel antiseptik, E. coli, S. thyposa, S. aureus, B. subtlis

\begin{abstract}
A research which antiseptic hand gel preparations containing the active leaf extract fraction ethanol Sungkai (Peronema canencens Jack.) has been done. This study aims to know is antiseptic activity Sungkai leaf fraction (P. canescens. Jack) in vitro against to several microbial pathogens in the preparation of antiseptic hand gel, and to know determine the best concentration of ethanol fraction Sungkai leaf in the preparation of antiseptic gel hands each strain of pathogenic bacteria. Test materials obtained by fractionation of the ethanol extract of the leaf fraction Sungkai, further formulated into a gel base antiseptic, tested its activity against several bacterial pathogens, and determine the best concentration of ethanol fraction Sungkai leaf in the preparation of antiseptic hand gel against Staphylococcus aureus, Salmonella thyposa, Escherichia coli and Bacillus subtilis bacteria. Antibacterial testing using method in vitro solid diffusion test. The results showed the concentration of ethanol fraction in gel dosage of active antiseptic against Staphylococcus aureus, Salmonella thyposa, Escherichia coli and Bacillus subtilis bacteria. The best concentration of ethanol extract in the preparation of antiseptic gel was $4 \%$ effective at inhibiting or kill the to three bacteria.
\end{abstract}

Keywords: P. canencens Jack, antiseptic gel, E. coli, S. thyposa, dan S. aureu, B. subtllis 


\section{PENDAHULUAN}

Penyakit infeksi akibat kerusakan jaringan kulit saat ini masih menjadi masalah serius di Indonesia, ditambah lagi dengan semakin meluasnya infeksi mikroorganisme yang diduga menginfeksi jaringan tubuh melalui tangan. Hal tersebut mendorong pentingnya penggalian sumber obatobatan antiseptik lain dari bahan alam. Tanaman obat tradisional diketahui potensial untuk dikembangkan lebih lanjut pada pengobatan penyakit infeksi, namun masih banyak yang belum dibuktikan bioaktivitasnya secara ilmiah [1]. Pemakaian antiseptik tangan dalam bentuk sediaan gel di kalangan masyarakat menengah keatas sudah menjadi suatu gaya hidup. Beberapa sediaan paten antiseptik tangan dapat dijumpai di pasaran. Cara pemakaiannya adalah dengan diteteskan pada telapak tangan, kemudian diratakan pada permukaan tangan. Meningkatnya keinginan masyarakat untuk menggunakan bahan alam atau "back to nature", ditanggapi dengan banyaknya produkproduk topikal berbahan aktif tanaman untuk perawatan kesehatan, kosmetik dan pencegahan penyakit [2].

Salah satu tumbuhan obat yang banyak tumbuh di Indonesia yang banyak dimanfaatkan adalah tumbuhan Sungkai (P. canescens. Jack). Pada suku Dayak di Kalimantan Timur sampai saat ini memanfaatkan tumbuhan disekitarnya untuk pengobatan ataupun perawatan kesehatan misalnya tumbuhan Sungkai ( $P$. canescens. Jack) suku verbenaceae pada bagian daun muda digunakan sebagai obat pilek, demam, obat cacingan (ringworms), dijadikan mandian bagi wanita selepas bersalin dan sebagai obat kumur pencegah sakit gigi [3].

Ekstrak dan fraksi daun Sungkai ( $P$. canencens Jack.) memiliki aktifitas sebagai antimikroba [4]. Menurut [1], ekstrak daun sungkai memiliki metabolit sekunder antara lain golongan senyawa golongan alkaloid, terpenoid - steroid, flavanoid, dan tanin, serta memiliki aktifitas antibakteri terhadap Stre. mutans, S. thyposa, B. subtilis dan $S$. aureus, dengan konsentrasi minimum ekstrak metanol yang memberikan aktivitas adalah $4 \%$.

\section{METODE PENELITIAN}

\section{Alat yang digunakan :}

Seperangkat alat ekstraksi dan fraksinasi, seperangkat alat evaporator, seperangkat alat sterilisasi (oven, auto clove), dan seperangkat alat inkubator, alat-alat gelas, mikro pipet, vortex mixer, cawan Petri, pipet mikro, timbangan analitik.

\section{Bahan yang diteliti :}

Fraksi ekstrak etanol 98\%, bahan penelitian : $\mathrm{NaCl}$ fisiologis $0,9 \%$, DMSO, medium uji Nutrien Agar (NA), pelarutpelarut organik tehnis, strain-strain mikroba uji (Basillus subtilis, Staphylococcus aureus, Bacillus subtillis dan Escherichia coli.). bahan-bahan penyusun basis Gel (Carbopol, Gliserin, TEA, $\quad \mathrm{Na}_{2} \mathrm{SO}_{3}, \quad$ Pengaroma, aquadestilata).

\section{Pengolahan dan ekstraksi.}

Daun P.canencens yang telah dikumpulkan dibersihkan dan dicuci dengan air, setelah dipisahkan bagian yang tidak diperlukan, kemudian dikeringkan dengan menggunakan oven suhu $40^{\circ} \mathrm{C}$ hingga bobot kering konstan. Daun yang telah kering kemudian dipotong-potong kecil, kemudian diekstraksi menggunakan pelarut metanol. Ekstrak metanol yang diperoleh selanjutnya difraksinasi Cair - padat menggunakan pelarut organik ; n-heksan, etilasetat dan etanol 98\%. Fraksi etanol $98 \%$ selanjutnya digunakan sebagai bahan aktif sediaan gel antiseptik.

\section{Pembuatan sediaan gel antiseptik}

Fraksi etanol 98\% daun Sungkai konsentrasi $\quad 4 \%$, selanjutnya 
diformulasikan ke dalam basis gel standar (stabil). Sediaan jadi hasil formulasi yang diperoleh selanjutnya dilakukan pengujian karakteristik sifat fisika dan kimia dengan berbagai parameter uji (viscositas, daya sebar, dan kestabilan $\mathrm{pH})$ sebelum dan sesudah penyimpanan pada berbagai suhu. Sediaan yang memiliki karakteristik fisik terbaik (stabil) dan sifat kimia (pH rentang 4,26,5 ) selanjutnya diuji aktivitas antibakterinya untuk menentukan nilai KBM dengan metode difusi agar padat.
Analisis Data.

Data hasil penelitian dianalisis dengan metode deskriptif-kwantitatif.

HASIL DAN PEMBAHASAN

\section{Karakteristik Fisika - Kimia Sediaan Gel Antiseptik}

1). Sifat fisik dan kimia sediaan gel antiseptic tangan ekstrak etanol daun sungkai diperoleh dapat dilihat pada Tabel 1.

Tabel 1. Hasil pengujian stabilitas (viscositas dan daya sebar) sediaan gel antiseptik pada berbagai suhu penyimpanan

\begin{tabular}{|c|c|c|c|c|c|c|c|c|c|}
\hline \multirow{3}{*}{$\begin{array}{c}\text { Formula } \\
(4 \% \\
\text { bahan } \\
\text { aktif })\end{array}$} & \multicolumn{8}{|c|}{ Suhu penyimpanan } & \multirow{3}{*}{$\begin{array}{c}\text { Periode } \\
\text { Penyim } \\
\text { panan }\end{array}$} \\
\hline & \multicolumn{2}{|c|}{$\begin{array}{c}\text { dingin } \\
\text { dipercepat } \\
\left(2^{\circ} \mathrm{C}\right)\end{array}$} & \multicolumn{2}{|c|}{$\begin{array}{l}\text { Dingin } \\
\text { normal } \\
\left(5^{\circ} \mathrm{C}\right)\end{array}$} & \multicolumn{2}{|c|}{$\begin{array}{c}\text { ruang } \\
\text { dipercepat } \\
\left(40^{\circ} \mathrm{C}\right)\end{array}$} & \multicolumn{2}{|c|}{$\begin{array}{l}\text { Kamar } \\
\left(27^{\circ} \mathrm{C}\right)\end{array}$} & \\
\hline & $\begin{array}{c}\text { Vis } \\
\text { (Pa.s) }\end{array}$ & $\begin{array}{c}\varnothing \\
(\mathrm{cm})\end{array}$ & $\begin{array}{c}\text { Vis } \\
\text { (Pa.s) }\end{array}$ & $\begin{array}{c}\varnothing \\
(\mathrm{cm})\end{array}$ & $\begin{array}{c}\text { Vis } \\
\text { (Pa.s) }\end{array}$ & $\begin{array}{c}\varnothing \\
(\mathrm{cm})\end{array}$ & $\begin{array}{c}\text { Vis } \\
\text { (Pa.s) }\end{array}$ & $\begin{array}{c}\varnothing \\
(\mathrm{cm})\end{array}$ & \\
\hline Sediaan 1 & - & - & - & 8 & - & - & 2,74 & 8 & 0 hari \\
\hline Sediaan 2 & 4,76 & 8 & 4,51 & 7,8 & 2,43 & 8,6 & 2,01 & 8,8 & 10 hari \\
\hline Sediaan 3 & 2,66 & 10,2 & 5,45 & 9,5 & 2,44 & 9,5 & 2,60 & 8,3 & 20 hari \\
\hline Sediaan 4 & 2,54 & 8,1 & 2,98 & 7,3 & 2,18 & 8,7 & 2,15 & 8,6 & 30 hari \\
\hline
\end{tabular}

Hasil pengujian karakteristik fisik gel antiseptik tangan meliputi: uji viscositas dan daya sebar dengan berbagai suhu penyimpanan yaitu : suhu dipercepat $2^{\circ} \mathrm{C}$, suhu dingin normal $5^{\circ} \mathrm{C}$ dan suhu ruang dipercepat $40^{\circ} \mathrm{C}$ mengalami penurunan nilai viscositas. Nilai Viscositas dan diameter daya sebar sediaan gel antiseptik penyimpanan pada suhu kamar $27^{\circ} \mathrm{C}$ menunjukan nilai viscositas dan daya sebar yang stabil. Perubahan nilai viscositas masih dalam rage yang dipersyaratkan. Hasil uji kestabilan $\mathrm{pH}$ sediaan gel dapat dilihat pada Tabel 2.

Tabel 2 Hasil pengujian kestabilan $\mathrm{pH}$ sediaan sediaan gel antiseptik pada berbagai suhu penyimpanan

\begin{tabular}{|c|c|c|c|c|c|c|c|}
\hline \multirow[b]{3}{*}{ Formula } & \multicolumn{6}{|c|}{ Nilai pH penyimpanan pada suhu } & \multirow[b]{3}{*}{$\begin{array}{c}\text { Periode } \\
\text { Penyimpanan }\end{array}$} \\
\hline & \multicolumn{2}{|c|}{$\mathrm{pH}$ Awal } & \multicolumn{4}{|c|}{$\mathrm{pH}$ akhir } & \\
\hline & $\begin{array}{c}\text { Suhu } \\
\text { dingin } \\
\left(5^{\circ} \mathrm{C}\right)\end{array}$ & $\begin{array}{l}\text { Suhu } \\
\text { kamar } \\
\left(27^{\circ} \mathrm{C}\right)\end{array}$ & $\begin{array}{l}\text { dingin } \\
\text { dipercep } \\
\text { at }\left(2^{\circ} \mathrm{C}\right)\end{array}$ & $\begin{array}{c}\text { dingin } \\
\text { normal } \\
\left(5^{\circ} \mathrm{C}\right)\end{array}$ & $\begin{array}{c}\text { ruang } \\
\text { dipercepa } \\
\mathrm{t}\left(40^{\circ} \mathrm{C}\right)\end{array}$ & $\begin{array}{l}\text { Suhu } \\
\text { Kamar } \\
\left(27^{\circ} \mathrm{C}\right)\end{array}$ & \\
\hline Sediaan 1 & - & 6,11 & - & - & - & 6,11 & 0 hari \\
\hline Sediaan 2 & - & 6,11 & 6,70 & 6,80 & 6,61 & 6,69 & 10 hari \\
\hline Sediaan 3 & - & 6,11 & 6,77 & 6,86 & 6,27 & 6,65 & 20 hari \\
\hline Sediaan 4 & - & 6,11 & 6,85 & 6,70 & 6,26 & 6,39 & 30 hari \\
\hline
\end{tabular}


Hasil pengujian karakteristik nilai $\mathrm{pH}$ sediaan gel antiseptik menunjukan perubahan nilai $\mathrm{pH}$ sediaan gel pada berbagai suhu penyimpanan menunjukkan bahwa perubahan nilai $\mathrm{pH}$ yang paling stabil adalah pada formula gel antiseptik penyimpanan pada suhu kamar, perubahan nilai $\mathrm{pH}$ masih dalam range $\mathrm{pH}$ lapisan epidermis kulit yaitu $\mathrm{pH}$ 4,5 - 6,5 dan $\mathrm{pH}$ dermis kulit yaitu $\mathrm{pH}$ $7,1-7,4$.

\section{Aktivitas Antimikroba Gel Antiseptik \\ Konsentrasi ekstrak yang diformulasikan ke dalam basis}

menggunakan konsentrasi $4 \%$, yang merupakan konsentrasi terbaik hasil penelitian sebelumnya. Bakteri yang digunakan untuk pengujian aktivitas sediaan gel antiseptik adalah bakteri Staphylococcus aureus, Bacillus subtilis. Salmonella thyposa dan Escherichia coli. Hasil pengujian aktivitas antimikroba sediaan gel antiseptik berdasarkan daya bunuh $(\mathrm{mm})$ sebelum penyimpanan dan setelah penyimpanan 30 hari dapat dilihat pada Tabel 3 dan 4, serta Grafik pada Gambar 1 dan 2.

Tabel 3 Aktivitas antimikroba sediaan gel antiseptic sebelum penyimpanan pada suhu kamar $27^{\circ} \mathrm{C}$

\begin{tabular}{lcccccc}
\hline \multicolumn{5}{c}{ Hasil Pengujian Formula Setelah Pembuatan Suhu Kamar } \\
\hline \multirow{2}{*}{ Mikroba Uji } & Konsentrasi & \multicolumn{5}{c}{ Diameter Zona Hambat (mm) } \\
\cline { 3 - 7 } & Ekstrak & $\mathrm{n} 1$ & $\mathrm{n} 2$ & $\mathrm{n} 3$ & Total & Rata-rata \\
\hline Staphylococcus aureus & $4 \%$ (capet 1) & 5,49 & 6,46 & 8,39 & 20,34 & 6,78 \\
Salmonella thyposa & $4 \%$ (capet 1) & 5,61 & 5,4 & 4,75 & 15,76 & 5,25 \\
Escerichia coli & $4 \%$ (capet 1) & 5,16 & 5,08 & 5,49 & 36,1 & 12,03 \\
Bacillus subtilis & $4 \%$ (capet 1) & 5,94 & 6,23 & 5,83 & 18,00 & 6,00 \\
\hline
\end{tabular}

\section{Keterangan:}

Medium uji Nutrien agar (NA)

Suhu inkubasi $=$ suhu $\operatorname{kamar} 27^{\circ} \mathrm{C}$

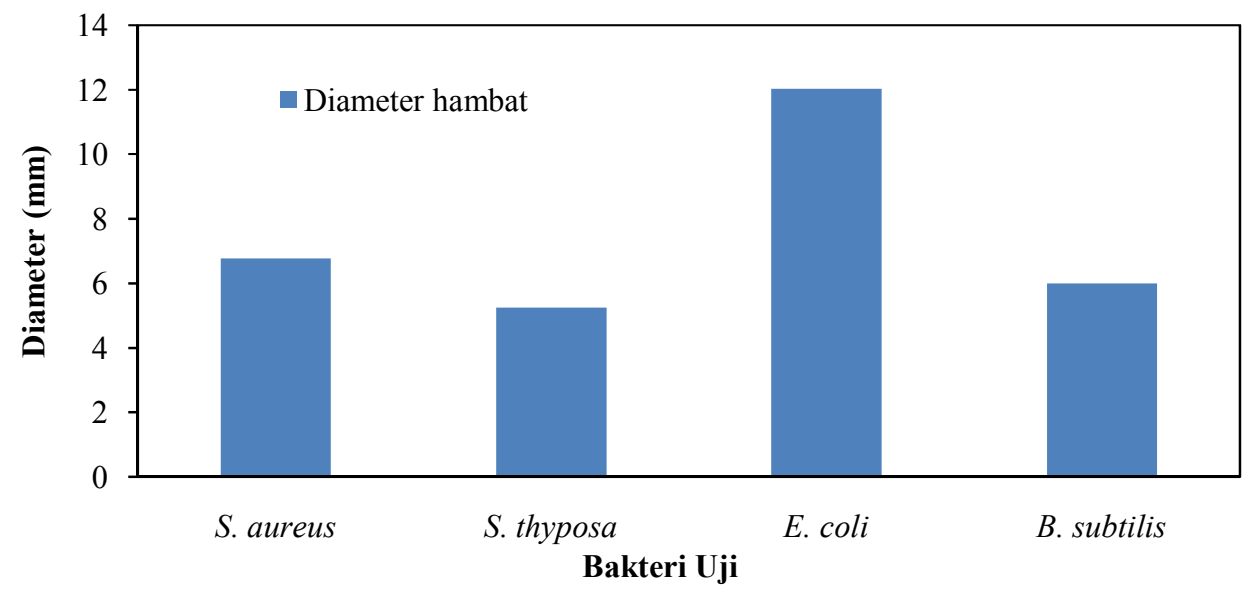

Gambar 1. Hasil uji aktivitas sediaan Gel antiseptik fraksi etanol daun Sungkai terhadap beberapa bakteri uji sebelum penyimpanan 


\section{1) Aktivitas antimikroba sediaan gel antiseptik sebelum penyimpanan}

Dari data dalam Tabel 3 dan

Gambar 1 menunjukan aktivitas daya hambat sediaan gel mengandung ekstrak daun sungkai terhadap 4 jenis bakteri menunjukkan bahwa efek antiseptik gel terbaik berturut-turut terhadap bakteri $E$. coli dengan rata - rata zona bunuh 12,3 $\mathrm{mm}$, terhadap bakteri $S$. aureus rata-rata zona hambat $6.78 \mathrm{~mm}$, terhadap bakteri $S$. thyposa rata-rata zona hambat 5.25 $\mathrm{mm}$, dan terhadap $B$. subtilis rata-rata zona hamabt adalah $6.00 \mathrm{~mm}$.

Tabel 4. Aktivitas antimikroba sediaan gel antiseptic setelah penyimpan 30 hari pada suhu $\operatorname{kamar} 27^{\circ} \mathrm{C}$

\begin{tabular}{lcccccc}
\hline \multicolumn{5}{c}{ Hasil Pengujian Formula Setelah 30 Hari Penyimpanan Suhu Kamar } \\
\hline \multirow{2}{*}{ Mikroba Uji } & Konsentrasi & \multicolumn{5}{c}{ Diameter Zona Hambat (mm) } \\
\cline { 3 - 7 } & Ekstrak & $\mathrm{n} 1$ & $\mathrm{n} 2$ & $\mathrm{n} 3$ & Total & Rata-rata \\
\hline Staphylococcus aureus & $4 \%$ & 1,99 & 2,58 & 2,39 & 6,96 & 2,32 \\
Salmonella thyposa & $4 \%$ & 1,73 & 2,29 & 1,36 & 5,38 & 1,79 \\
Escerichia coli & $4 \%$ & 1,86 & 2,4 & 1,74 & 6,00 & 2,00 \\
Bacillus subtilis & $4 \%$ & 0 & 0 & 0 & 0 & 0 \\
\hline
\end{tabular}

Keterangan:

Medium uji Nutrien agar (NA)

Suhu inkubasi $=$ suhu $\operatorname{kamar} 27^{\circ} \mathrm{C}$

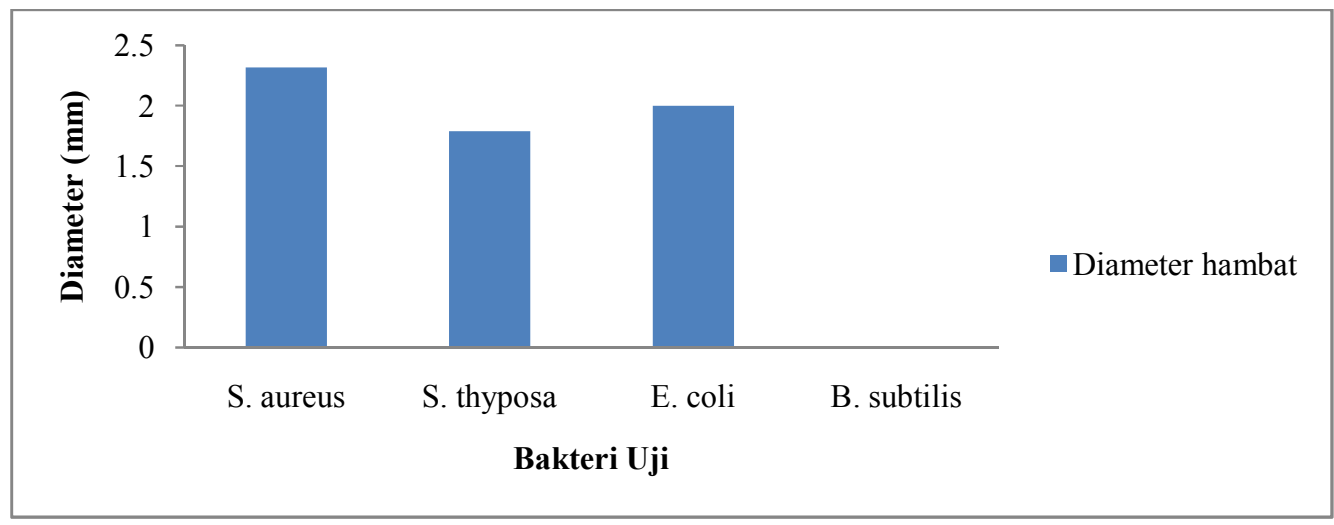

Gambar 2. Hasil uji aktivitas sediaan Gel antiseptik fraksi etanol daun Sungkai terhadap beberapa bakteri uji setelah penyimpanan

\section{2) Aktivitas Aktivitas antimikroba sediaan gel antiseptic setelah penyimpanan}

Berdasarkan data dalam Tabel 4 dan Gambar 2 menunjukan aktivitas daya bunuh sediaan gel mengandung ekstrak daun sungkai mengalami penurunan daya hambat (aktivitas), perubahan paling menonjol terlihat pada aktivitas gel terhadap bakteri $B$. subtilis dimana pada penyimpanan selama 30 hari aktivitas aktiseptinya menjadi nol. Penurunan kemampuan daya hambat ini menunjukkan bahwa ada pengaruh lama penyimpanan terhadap kestabilan senyawa kimia dalam formula gel antiseptik, hal ini menunjukkan bahwa selama penyimpanan diduga senyawa aktif dalam ekstrak daun sungkai mengalami interaksi dengan bahan basis gel yang digunakan. Oleh karena itu diperluakan evaluasi terhadap interaksi yang terjadi antara senyawa kimia yang 
terkandung dalam ekstrak dengan bahan basis gel yang digunakan.

Kemampuan fraksi ekstrak etanol membunuh mikroba uji diduga oleh aktivitas metabolit sekunder yang terdapat dalam ekstrak. Golongan metabolit sekunder yang terdapat dalam daun Sungkai adalah golongan polifenol yaitu flavonoid dan Tanin [1]. Mekanisme antibakteri metabolit sekunder golongan senyawa polifenol merupakan kelompok terbesar dalam tumbuhan salah satunya adalah tanin yang memiliki aktivitas antibakteri, secara garis besar mekanisme yang diperkirakan yaitu toksisitas golongan senyawa polifenol dapat merusak membran sel bakteri. Mekanisme antibakteri golongan flavonoid dengan cara membentuk senyawa kompleks terhadap protein ekstraseluler yang mengganggu integritas membran sel bakteri [5]. Menurut [6] flavanoid merupakan senyawa fenol, sementara senyawa fenol dapat bersifat koagulator protein.

Menurut [7], tanin merupakan kelompok senyawa polifenol yang memiliki aktifitas antibakteri, mekanisme kerja tanin sebagai antibakteri diduga dapat mengkerutkan dinding sel atau membran sel sehingga mengganggu permeabilitas sel itu sendiri, akibat terganggunya permeabilitas, sel tidak dapat melakukan aktivitas hidup sehingga pertumbuhannya terhambat atau bahkan mati. Menurut [8] menyatakan bahwa tanin juga mempunyai daya antibakteri dengan cara mempresipitasi protein, karena diduga tanin mempunyai efek yang sama dengan senyawa fenolik. Efek antibakteri tanin antara lain melalui reaksi dengan membran sel, inaktivasi enzim, dan destruksi atau inaktivasi fungsi materi genetic [9]. Selain itu kemampuan senyawa antibakteri dalam menghambat pertumbuhan bakteri dipengaruhi oleh kestabilan terhadap protein, lipid, garam dan tingkat keasaman $(\mathrm{pH})$ dalam medium pertumbuhan [10].

\section{KESIMPULAN}

Berdasarkan hasil penelitian yang telah dilaksanakan diperoleh kesimpulan : Karakteristik fisik dan kimia sediaan gel antiseptik berbahan aktif 4\% ekstrak etanol daun Sungkai stabil secara fisik dan kimia, dengan $\mathrm{pH}$ rentang 6,2 - 7,4 pada penyimpanan suhu kamar $27^{\circ} \mathrm{C}$. Aktivitas antibakteri sediaan gel antiseptik berbahan aktif $4 \%$ fraksi ekstrak etanol sebelum penyimpanan aktif terhadap bakteri Staphylococcus aureus, Salmonela thyposa, Escherichia coli dan Bacillus subtilis. Sedangkan efek sediaan gel antiseptik sesudah penyimpanan aktif terhadap bakteri Staphylococcus aureus, Salmonela thyposa dan Escherichia coli.

\section{UCAPAN TERIMA KASIH}

Ucapan terima kasih kepada Dekan Fakultas Fakultas Farmasi yang telah memberikan dana hibah penelitian, dan kepada kepala Laboratorium Farmakatropis FF. Unmul yang telah memberikan izin menggunakan laboratorium untuk penelitian.

\section{DAFTAR PUSTAKA}

1. Ibrahim., A., Kuncoro., H. 2012. Identifikasi Metabolit Sekunder dan Aktivitas Antibakteri Ekstrak Daun Sungkai (Peronema canescens Jack.) terhadap Beberapa Bakteri Patogen. Journal of Trophycal Pharmacy and Chemistry. 2. (1). 8 - 18.

2. Sari, R., dan Isadartuti. 2006. Studi Efektivitas Sediaan Gel Antiseptik Tangan Ekstrak Daun Sirih (Piper betle Linn). Majalah Farmasi Indonesia. 17. (14). 164.

3. Mardi. 2010. Koleksi Herba Institut Penyelidikan dan Kemajuan Pertanian Malaysia. (Online). http://wannura.wordpress.com). diakses tanggal 12 Juni 2011 
4. Hadi., I., 2011. Identifikasi Metabolit Sekunder dan Aktivitas Antibakteri Ekstrak Daun Sungkai (P. canencens Jack.) Skripsi Sarjana. Fakultas Farmasi Universitas Mulawarman.

5. Ibrahim., A., dkk. 2013. Efek Antimikroba Sediaan Salep Kulit Berbahan Aktif Ekstrak Etil Asetat Daun Sungkai (Peronema Canencens Jack.) Terhadap Bakteri Patogen Penginfeksi Luka Bakar. Journal of Trophycal Pharmacy and Chemistry. 2. (3). 125-131.

6. Dwidjoseputro. 2005. Dasar-Dasar Mikrobiologi. Djambaran; Jakarta.

7. Ajizah, A. 2004. Sensitivitas Salmonella Typhimurium Terhadap Ekstrak Daun Psidium Guajava L. Bioscientiae.1.(1). 31-38
8. Masduki I, 1996. Efek Antibakteri Ekstrak Biji Pinang (Areca catechu) terhadap S. aureus dan E. coli. Cermin Dunia Kedokteran. 109. 2124

9. Akiyama, H., Fuji., Yamasaki., dkk., 2001. Antibacterial Action of Several Tannins Agains Staphylococcus aureus. Journal of Antimicrobia Cahemotherapy. 48. 487-491.

10. Djide, N, \& Sartini. 2008. Analisis Mikrrobiologi Farmasi. Universitas Hasanuddin; Makassar. 